\title{
ABCC6 knockdown in HepG2 cells induces a senescent-like cell phenotype
}

\author{
Rocchina Miglionico ${ }^{1}$, Angela Ostuni ${ }^{1}$, Maria Francesca Armentano ${ }^{1}$, Luigi Milella ${ }^{1}$, Elvira Crescenzi ${ }^{2}$,
} Monica Carmosino ${ }^{1 *}$ and Faustino Bisaccia ${ }^{1 *}$

\author{
* Correspondence: \\ monica.carmosino@unibas.it: \\ faustino.bisaccia@unibas.it \\ ${ }^{1}$ Department of Sciences, University \\ of Basilicata, Via dell'Ateneo Lucano, \\ 85100 Potenza, Italy \\ Full list of author information is \\ available at the end of the article
}

\begin{abstract}
Background: Pseudoxanthoma elasticum (PXE) is characterized by progressive ectopic mineralization of elastic fibers in dermal, ocular and vascular tissues. No effective treatment exists. It is caused by inactivating mutations in the gene encoding for the ATP-binding cassette, sub-family C member 6 transporter (ABCC6), which is mainly expressed in the liver. The ABCC6 substrate (s) and the PXE pathomechanism remain unknown. Recent studies have shown that overexpression of ABCC6 in HEK293 cells results in efflux of ATP, which is rapidly converted into nucleoside monophosphates and pyrophosphate (PPi). Since the latter inhibits mineralization, it was proposed that the absence of circulating PPi in PXE patients results in the characteristic ectopic mineralization. These studies also demonstrated that the presence of ABCC6 modifies cell secretory activity and suggested that ABCC6 can change the cell phenotype.
\end{abstract}

Methods: Stable ABCC6 knockdown HepG2 clones were generated using small hairpin RNA (shRNA) technology. The intracellular glutathione and ROS levels were determined. Experiments using cell cycle analysis, real-time PCR and western blot were performed on genes involved in the senescence phenotype.

Results: To shed light on the physiological role of ABCC6, we focused on the phenotype of HepG2 cells that lack ABCC6 activity. Interestingly, we found that ABCC6 knockdown HepG2 cells show: 1) intracellular reductive stress; 2) cell cycle arrest in G1 phase; 3) upregulation of p21 ${ }^{\mathrm{Cip}} \mathrm{p} 53$ independent; and 4) downregulation of lamin A/C.

Conclusions: These findings show that the absence of ABCC6 profoundly changes the HepG2 phenotype, suggesting that the PXE syndrome is a complex metabolic disease that is not exclusively related to the absence of pyrophosphate in the bloodstream.

Keywords: ABCC6, Cell cycle, Senescence, Reductive stress

\section{Background}

ATP-binding cassette sub-family $\mathrm{C}$ member 6 transporter (ABCC6) is an ATPdependent transporter mainly found in the basolateral plasma membrane of hepatic and kidney cells. Mutations in the gene were associated with pseudoxanthoma elasticum (PXE), an autosomal recessive disease characterized by progressive ectopic calcification of elastic fibers in dermal, ocular and vascular tissues [1-3]. It is currently known that mutations in the $A B C C 6$ gene are associated with some cases of

(c) The Author(s). 2017 Open Access This article is distributed under the terms of the Creative Commons Attribution 4.0 International License (http://creativecommons.org/licenses/by/4.0/), which permits unrestricted use, distribution, and reproduction in any medium, provided you give appropriate credit to the original author(s) and the source, provide a link to the Creative Commons license, and indicate if changes were made. The Creative Commons Public Domain Dedication waiver (http://creativecommons.org/ publicdomain/zero/1.0/) applies to the data made available in this article, unless otherwise stated. 
generalized arterial calcification of infancy (GACI) [4] and are also responsible for dystrophic cardiac calcification (DCC) in mice, an autosomal recessive trait characterized by calcium phosphate deposits in myocardial tissue [5-7]. Arterial calcification due to CD73 deficiency (ACDC) is a closely related ectopic disorder that probably shares a common pathogenetic pathway with PXE [8].

One early surprising observation was that $A B C C 6$ is primarily expressed in the liver, to a lesser extent in the proximal tubules of the kidneys, and at very low level, if at all, in tissues clinically affected by PXE $[9,10]$. These observations raised a challenging question on the pathomechanism of PXE. The "metabolic hypothesis" postulates that the absence of ABCC6 activity in the liver results in a deficiency of circulating factors that are physiologically required to prevent aberrant mineralization in the connective tissues under normal calcium and phosphate homeostatic conditions [11]. Therefore, in recent years, particular attention has been paid to the analysis of serum and fibroblasts from PXE patients $[12,13]$. Proteomics and metabolomics studies on PXE patient fibroblasts revealed increased oxidative stress parameters in these cells [14].

Although ABCC6 is not an ATP transporter [15], recent studies have shown that the overexpression of ABCC6 in HEK293 cells results in the efflux of ATP and other nucleoside triphosphates, which are then rapidly converted into nucleoside monophosphates and pyrophosphate (PPi). Since PPi inhibits mineralization, it was proposed that the absence of circulating PPi in PXE patients results in the characteristic ectopic mineralization of PXE $[15,16]$. Notably, these findings also demonstrate that the presence of ABCC6 modifies the cell secretory activity, suggesting that ABCC6 can change the cell phenotype.

However, the role of ABCC6 in the liver has been poorly investigated thus far. To shed light on its physiological role, several structural studies on its domains were performed [17-19]. Here, we focused our attention on the phenotype of HepG2 cells that lack ABCC6 activity. Our previous studies of ABCC6 knockdown HepG2 cells showed dysregulation of some genes related with the calcification processes, such as the tissue nonspecific alkaline phosphatase (TNAP), the cluster of differentiation 73 (CD73) and osteopontin (OPN) [20]. Importantly, the pro-mineralization genes dysregulated in ABCC6 knockdown HepG2 cells encode both the proteins expressed on the extracellular face of the hepatocyte plasma membrane (TNAP, CD73) and those released into the bloodstream (OPN, Fetuin A). TNAP and CD73 can exert their activities in the extracellular space and in extra-hepatic tissues, respectively, in the absence of clinically evident modifications in hepatocyte metabolism or function.

In an attempt to shed further light on the functional role of ABCC6 in the liver and on the complex pathogenesis of PXE, we focused on characterizing the cellular phenotype of $A B C C 6$ knockdown HepG2 cells. We found that these cells show typical features of replicative senescence and the reductive state, suggesting novel and important aspects in the pathophysiological role of ABCC6 in the PXE.

\section{Methods}

\section{Cell culture and generation of stable shRNA ABCC6 knockdown clones}

HepG2 cells were maintained in Dulbecco's modified essential medium (DMEM) containing $4.5 \mathrm{~g} / \mathrm{l}$ glucose, supplemented with $10 \%$ fetal bovine serum (FBS), $2 \mathrm{mM} \mathrm{L-}$ 
glutamine, $100 \mathrm{U} / \mathrm{ml}$ penicillin and $100 \mu \mathrm{g} / \mathrm{ml}$ streptomycin, at $37{ }^{\circ} \mathrm{C}$ in an atmosphere of $5 \% \mathrm{CO}_{2}$. All the experiments were performed using cells at $70 \%$ confluence. Stable clones were generated using the ABCC6-shRNA targeting sequence 5'-AGCTTAGACGCGAGAGGTCCATCAAGTCA-3', as previously described [20].

\section{Measurement of intracellular reduced glutathione}

Intracellular reduced glutathione (GSH) and oxidised glutathione (GSSG) levels were measured using a glutathione fluorometric assay kit (BioVision) according to the manufacturer's protocol. In this assay, o-phthalaldehyde (OPA) reacts with GSH present in the sample emitting a fluorescent signal (ex. $340 \mathrm{~nm}$, em. $420 \mathrm{~nm}$ ) that is measured using a GLOMAX Multidetection System (Promega). To measure GSSG specifically, a GSH Quencher is added to remove GSH, preventing its reaction with OPA. GSSG is reduced to GSH, which is measured using the preceding method. The levels of intracellular GSH were quantified using a standard curve for known amounts of GSH. The GSH/GSSG ratio was calculated as an indicator of redox balance.

\section{Determination of intracellular reactive oxygen species}

The intracellular levels of reactive oxygen species (ROS) were determined using a cell permeable fluorogenic probe, $2^{\prime}, 7^{\prime}$-dichlorofluorescein diacetate (DCFH-DA). Once inside the cells, it is converted by intracellular esterases into the cell membraneimpermeable non-fluorescent compound DCFH, which rapidly oxidizes, becoming the highly fluorescent compound dichloro-fluorescein (DCF) in the presence of ROS. Briefly, $2 \times 10^{5}$ cells were seeded into 12 -well plates and, after $24 \mathrm{~h}$, incubated with $1 \mu \mathrm{M}$ DCFH-DA for $1 \mathrm{~h}$ at $37{ }^{\circ} \mathrm{C}$ in a humidified $5 \% \mathrm{CO}_{2}$ atmosphere. The cells were then trypsinized, washed with PBS and analyzed via FACScan flow cytometry (BD Biosciences) using $488 \mathrm{~nm}$ excitation and $530 \mathrm{~nm}$ emission wavelengths.

\section{Cell cycle analysis}

Cells were synchronized at the G0 phase by serum deprivation for $24 \mathrm{~h}$, restimulated with $10 \%$ serum for $24 \mathrm{~h}$ and incubated with $30 \mu \mathrm{M}$ bromodeoxyuridine (BrdU, Sigma) for $30 \mathrm{~min}$ at $37{ }^{\circ} \mathrm{C}$. Cells were fixed with $70 \%$ ethanol in PBS, washed twice with PBS and incubated with $2 \mathrm{M} \mathrm{HCl}$ for $30 \mathrm{~min}$ at room temperature. The cells were then washed twice with PBS, Tween-20 0.1\% (PBST) and incubated with anti-BrdU-FITC (BD Biosciences) for $1 \mathrm{~h}$ at room temperature. After incubation, the cells were washed with PBS, resuspended in PBS with $5 \mu \mathrm{g} / \mathrm{ml}$ propidium iodide (Sigma-Aldrich) and $50 \mu \mathrm{g} / \mathrm{ml}$ RNase DNase-free (Roche) and incubated at room temperature for $20 \mathrm{~min}$. Cells were analyzed using a C6 Accuri Flow Cytometer (Beckman Coulter, Inc.) and Modfit software (Verity Software House Inc.).

\section{Senescence-associated $\beta$-galactosidase staining assay}

Cytochemical staining for senescence-associated $\beta$-galactosidase was determined as described by Dimri et al. [21]. Briefly, cells were seeded into 12 -well plates $\left(2 \times 10^{5}\right.$ cells/ well) and after $24 \mathrm{~h}$, cells were fixed with $2 \%$ formaldehyde and $0.2 \%$ glutaraldehyde for $7 \mathrm{~min}$ at room temperature. After two washes in PBS, the cells were incubated for $2 \mathrm{~h}$ at $37^{\circ} \mathrm{C}$ with fresh staining solution containing $0.1 \%$ of 5 -bromo-4-chloro-3-indolyl $\beta$ - 
D-galactopyranoside (X-gal), $5 \mathrm{mM}$ potassium ferrocyanide, $5 \mathrm{mM}$ potassium ferricyanide, $150 \mathrm{mM} \mathrm{NaCl}$ and $2 \mathrm{mM} \mathrm{MgCl} 2$ in $40 \mathrm{mM}$ citric acid/sodium phosphate, $\mathrm{pH} 6.0$ (Sigma-Aldrich). Cells were examined under a light microscope and representative fields were photographed using a Nikon Coolpix P6000.

\section{RT-PCR and real-time PCR}

Total RNA was extracted using the GenElute Mammalian Total RNA Miniprep Kit (Sigma-Aldrich) according to the manufacturer's instructions. The RNA was transcribed to cDNA using oligo (dT) primers and the GeneAmp RNA PCR Core Kit (Applied Biosystems), and the cDNA was amplified via real-time PCR using PowerSYBR Green PCR Master Mix (Promega) on the 7500 Fast Real-Time PCR System (Applied Biosystems).

The following primers were designed with the Allele ID program to span exon-exon junctions eliminating undesirable genomic DNA amplification: p53, forward: 5'TGAATGAGGCCTTGGAACTC-3' , reverse: 5'-ACTTCAGGTGGCTGGAGTG3-'; p21 ${ }^{\text {Cip }}$, forward: 5'-CTGTCTTGTACCCTTGTGCCT-3', reverse: 5'-CGTTTGGAG TGGTAGAAATCTGTC-3'; lamin A/C, forward: 5' -GTGGATGCTGAGAACAGGCT3', reverse: 5'-CACGCAGCTCCTCACTGTAG-3'; and $\beta$-actin, forward: 5 '-CCTGGC ACCCAGCACAAT-3', reverse: 5'-GCCGATCCACACGGAGTACT-3'.

\section{Western blot analysis}

Cells $\left(5 \times 10^{5}\right)$ were lysed in RIPA buffer $(0.1 \%$ sodium dodecyl sulfate, $1 \%$ NP-40 and $0.5 \%$ sodium deoxycholate in PBS at $\mathrm{pH}$ 7.4) supplemented with a protease and phosphatase inhibitor cocktail. The proteins $(100 \mu \mathrm{g})$ were loaded onto SDS-PAGE gels and electrophoretically transferred to nitrocellulose membranes (Amersham Bioscience). After blocking with $5 \%$ non-fat dry milk in TRIS buffer saline-Tween 20, the blots were incubated overnight at $4{ }^{\circ} \mathrm{C}$ with either 1:1000 anti-lamin A/C (Cell Signaling Antibodies) or 1:1000 anti-p21 ${ }^{\mathrm{Cip}}$ (Abcam) or 1:1000 anti-p53 (Abcam) primary antibodies, and then with appropriate horseradish peroxidase-conjugated secondary antibody. Proteins were detected using Enhanced Chemiluminescence reagents (ECL, Promega) and chemiluminescence was detected with a Chemidoc XRS detection system equipped with Image Lab Software for image acquisition (Bio-Rad). The quantification of protein bands was performed by determining the relative optical density using ImageJ software (National Institutes of Health, Bethesda, MD).

\section{Results}

ABCC6 knockdown HepG2 cells accumulate GSH and show a 'reductive stress' state

Since an increase in the oxidative state was observed in PXE fibroblasts [14, 22], we first checked whether the knockdown of $A B C C 6$ in HepG2 cells might affect the intracellular GSH/GSSG ratio. We performed all experiments in stable $A B C C 6$ knockdown HepG2 cells that had been previously generated and studied [20]. Unexpectedly, as shown in Fig. 1a, the intracellular GSH/GSSG ratio increased by about $40 \%$ in $A B C C 6$ knockdown cells (ABCC6-shRNA) compared to control cells stably transfected with scrambled shRNA (scr-shRNA). 
$\mathbf{a}$
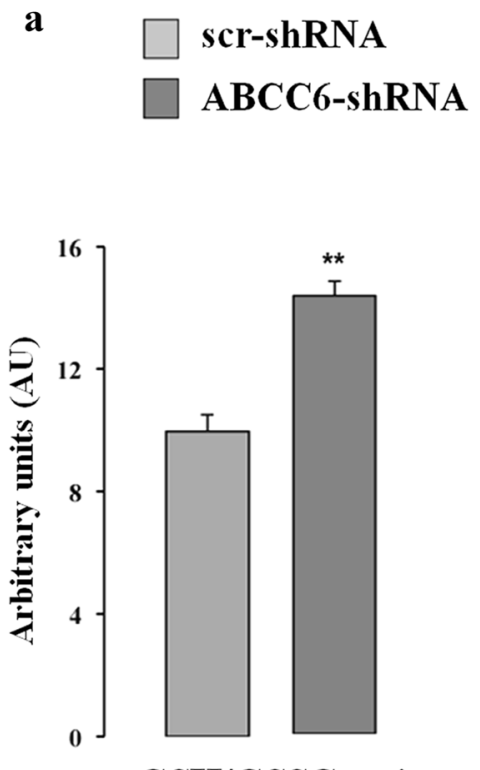

GSH/GSSG ratio

\section{b scr-shRNA ABCC6-shRNA}

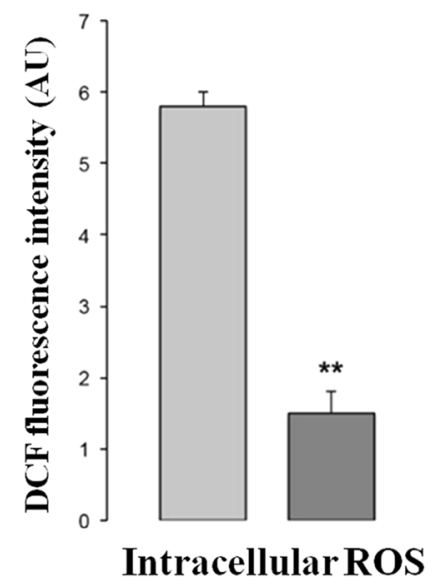

Fig. 1 Effect of ABCC6 knockdown on GSH/GSSG ratio and ROS generation. a - The GSH/GSSG ratio was determined using the glutathione fluorometric assay, as described in the Materials and Methods section. The results are reported as means \pm SD of three independent experiments performed in triplicate. $\mathbf{b}-$ ROS production was detected via FACS using a DCFH-DA fluorescent probe as described in the Materials and Methods section. Scr-shRNA: HepG2 cells stably transfected with scrambled shRNA; ABCC6-shRNA: HepG2 cells stably transfected with $A B C C 6$-shRNA. The values are the means \pm SD of three replicates from three independent experiments. ${ }^{* *} p<0.01$. Unpaired data were assessed for statistical significance using Student's $t$ test

Because of the cysteine residue, GSH is readily oxidized non-enzymatically to glutathione disulfide (GSSG) by electrophilic substances (e.g., free radicals and reactive oxygen/nitrogen species), thus effectively scavenging free radicals and other reactive oxygen species (ROS). Accordingly, we found that ROS levels, measured using the fluorescent dye, 2',7'-dichlorodihydrofluorescein diacetate $\left(\mathrm{H}_{2} \mathrm{DCF}-\mathrm{DA}\right)$, showed a strong and significant 5-fold decrease in ABCC6 knockdown cells compared to control HepG2 cells (Fig. 1b). The observed ROS reduction does not depend on DCF efflux mediated by multidrug resistance-associated proteins (MRP) [23]. In fact, the expression of some MRP transporters (ABCC1, $A B C C 2$ and $A B C B 1$ ), measured using realtime PCR, does not change in ABCC6 knockdown cells compared to control cells (data not shown).

These data suggest that the knockdown of ABCC6 in HepG2 cells causes the 'reductive stress' state [24].

\section{ABCC6 knockdown HepG2 cells show impaired cell cycle with cell accumulation in G1 phase}

Several studies have suggested the role of intracellular GSH in cell proliferation, showing that each phase in the life of the cells is characterized by a particular redox state, and that proliferating cells are in a mostly reduced state $[25,26]$.

We analyzed the cell cycle in control and ABCC6 knockdown HepG2 cells. Briefly, $24 \mathrm{~h}$ serum starvation was used to synchronize cells in G0 phase. BrdU and PI 
incorporation were analyzed via flow cytometry $24 \mathrm{~h}$ after the addition of serum. We found that ABCC6 knockdown cells delay G1 exit (Fig. 2a). After $24 \mathrm{~h}$, about $50 \%$ of the control cells but only about $20 \%$ of $A B C C 6$ knockdown cells had exited G1, suggesting that the reduced expression of ABCC6 significantly retards $\mathrm{G} 1$ to $\mathrm{S}$ transition and slows cell growth.

We then analyzed the activity of the well-known cellular senescence biomarker senescence-associated $\beta$-galactosidase (SA- $\beta$-Gal) at $\mathrm{pH} 6.0$ [27]. As shown in Fig. 2c, ABCC6 knockdown HepG2 cells show a roughly 8-fold increase in the number of cells with blue precipitates after incubation with the SA- $\beta$-gal staining solution, consistent with senescent phenotype. In senescent cells, the cyclin-dependent kinases (CDK) that selectively regulate cell entry into the different cycle phases, are inactivated by CDK inhibitors (CDKI).

Fig. 3a shows the increase in $\mathrm{p} 21^{\mathrm{Cip}}$ transcript levels in ABCC6 knockdown cells compared to control cells, as confirmed by western blotting analysis (Fig. 3b and c), while p53 expression was unaffected by ABCC6 silencing (Fig. 3).

Since nuclear abnormalities and changes in lamin $\mathrm{A} / \mathrm{C}$ also occur during the aging process of wild-type cells [28], we monitored the expression levels of both lamin A/C messenger and protein. Real time PCR data show a decrease of about $60 \%$ in lamin A/C mRNA in ABCC6 knockdown cells compared to control cells (Fig. 4a). Western

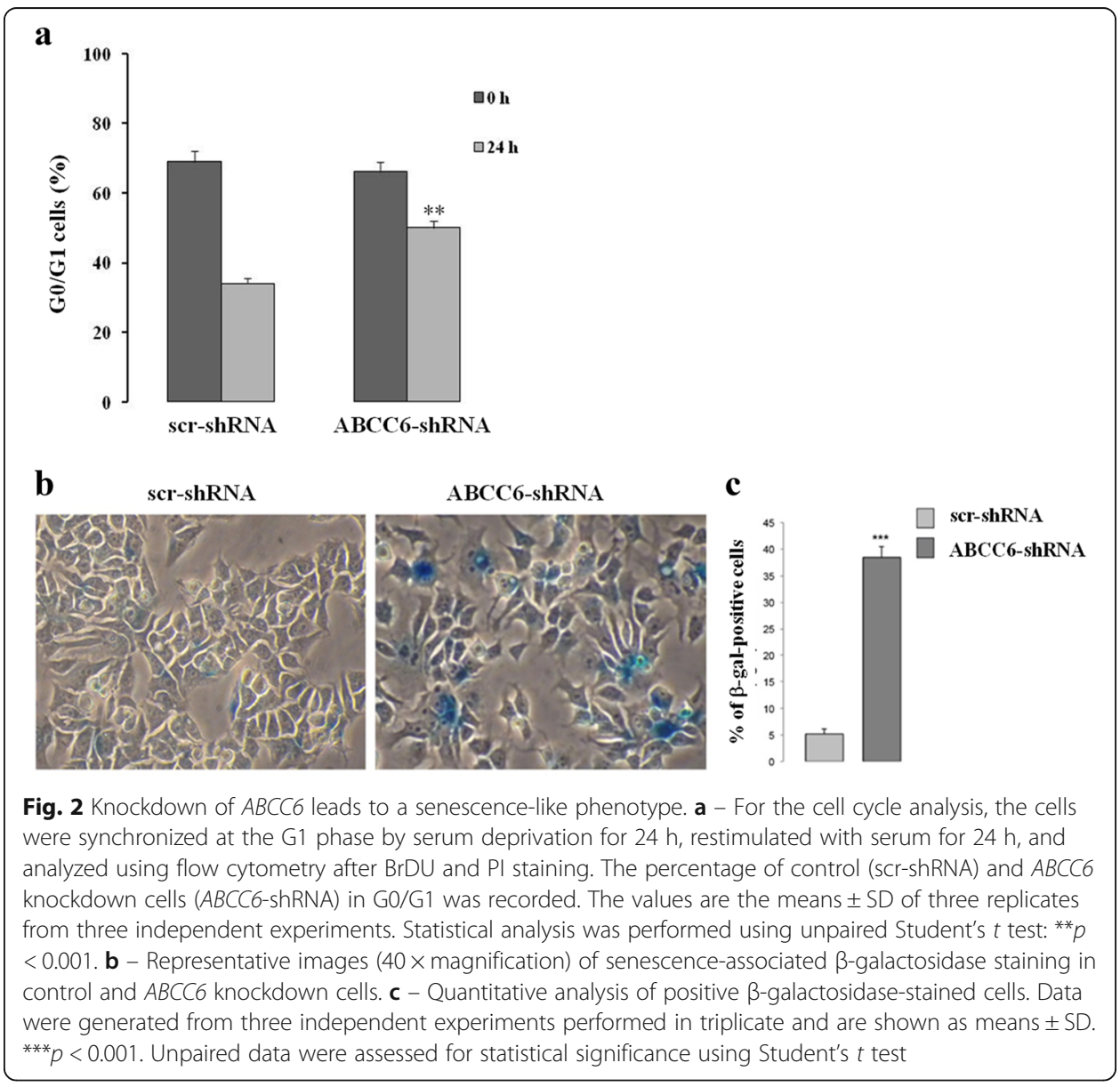


a

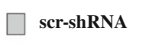

$\square$ ABCC6-shRNA

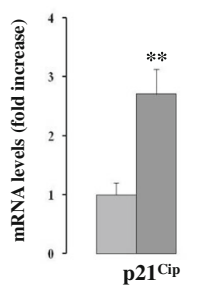

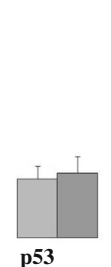

b

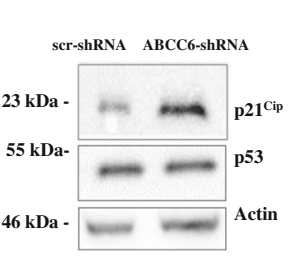

c

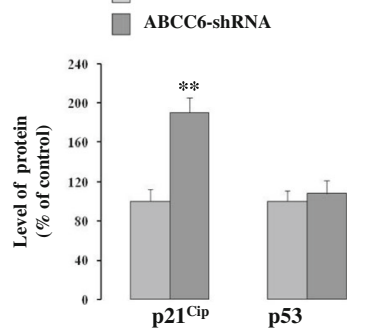

Fig. 3 Knockdown of $A B C C 6$ induces alterations in gene expression. $\mathbf{a}-\mathrm{p} 21^{\mathrm{cip}}$ and $\mathrm{p} 53 \mathrm{mRNA}$ levels were quantified with real-time PCR in control (scr-shRNA) and ABCC6 knockdown cells (ABCC6-shRNA), using $\beta$ actin as the internal control. Data are expressed as the means $\pm S D(n=3)$. $\mathbf{b}$ - Representative western blots of p21 ${ }^{\text {cip }}$ and p53 in control and ABCC6 knockdown cells. $\beta$-actin was used as a loading control. c - Densitometric analysis of the immunoreactive bands from three independent experiments (means \pm SD). ${ }^{* *} p<0.01$. Unpaired data were assessed for statistical significance using Student's $t$ test

blotting analysis shows a significant decrease in lamin A/C expression in $A B C C 6$ knockdown cells compared to control cells (Fig. 4b and c).

\section{Discussion}

Previous experiments on PXE dermal fibroblasts have shown an increase in ROS levels that has been suggested to be the cause of major PXE injuries [14, 22]. Unlike the case of fibroblasts, we find that the knockdown of $A B C C 6$ in HepG2 cells induces a significant increase in the intracellular levels of GSH and a reduction in ROS levels that could reflect the absence of PXE symptoms in the liver. However, antioxidant therapy failed to improve the clinical manifestation of PXE patients [29] and failed to counteract the mineralization in $A b c c 6^{-1-}$ mice [30], clearly suggesting that the absence of normal circulating levels of GSH is not the main pathomechanism underlying PXE.

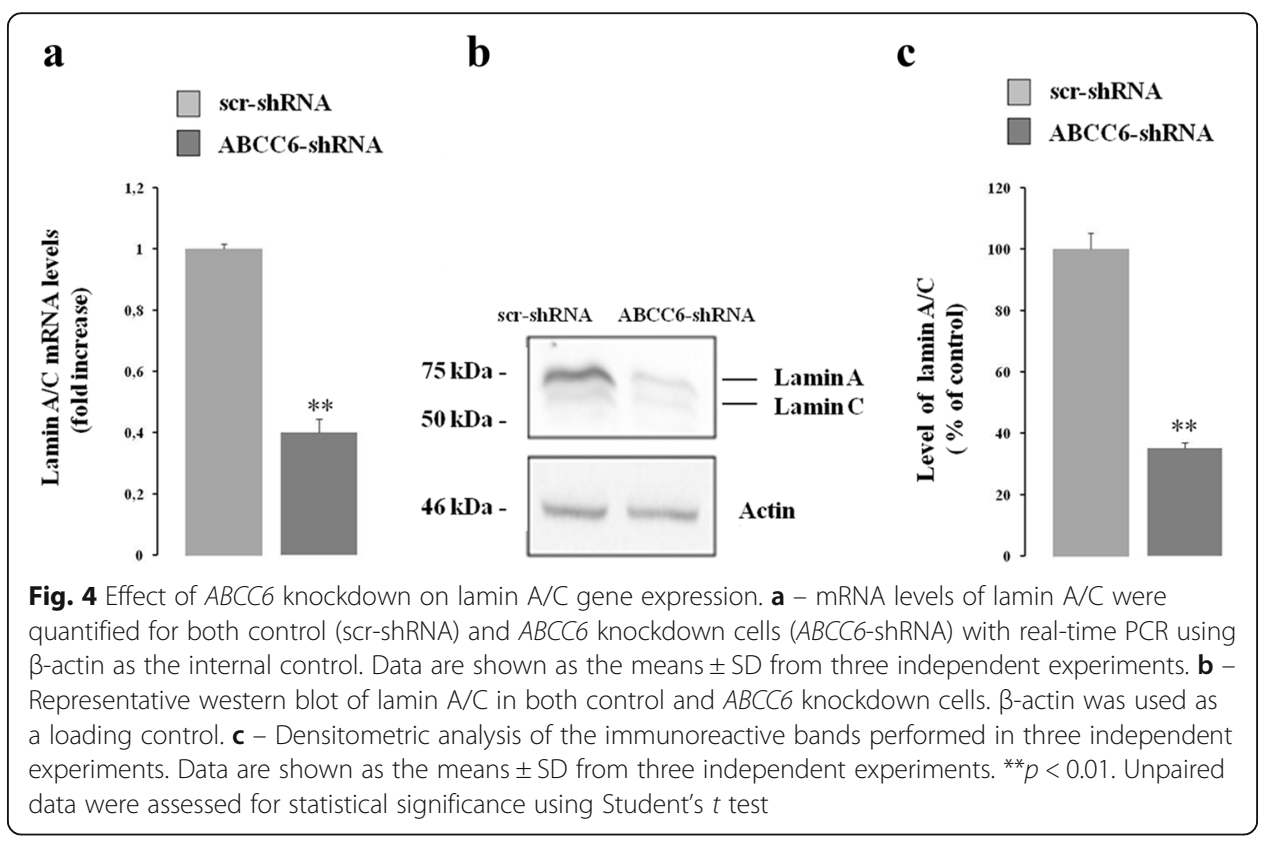


The observed cell cycle delay in the G1 phase could closely correlate to the intracellular ROS reduction, suggesting a functional inextricable relationship between ROS levels and G1/S cell cycle status, according to several studies [31, 32].

The change in the intracellular redox state observed in ABCC6 knockdown HepG2 cells may also explain the gene dysregulation found in both the previous study [20] and the present one. Accordingly, the modulation of the activity of several transcription factors by thiol redox state has been extensively reviewed. Redox regulation of DNA-protein interaction is an important step through which transcription factors can control gene transcription. Crucial cysteine residues have been discovered in the DNA-binding domain of several transcription factors and found to modulate their ability to bind DNA [33].

Furthermore, de Boussac et al. showed a correlation between ROS levels and ABCC6 expression, demonstrating that oxidative stress induced by vitamin $\mathrm{K} 3$ and tert-butylhydroquinone inhibits $\mathrm{ABCC6}$ expression [34]. The decrease in lamin A/C expression found in $A B C C 6$ knockdown cells may impinge on gene expression profiles, as shown for other pathophysiological conditions associated with lamin A dysregulation [35]. As a consequence, $A B C C 6$ knockdown HepG2 cells, which show a characteristic gene expression profile, could also adopt an altered secretory phenotype that may modify the tissue microenvironment, as already shown for several types of senescent cells [36, 37] including senescent hepatocytes [38]. Concurrent with this hypothesis, a recent study shows that abrogated ABCC6 function causes alterations in the metabolic profile of the liver, which aligns with the concept of PXE being a metabolic disease originating from liver disturbance [39].

\section{Conclusions}

All findings show that the knockdown of $A B C C 6$ changes the cellular phenotype and suggest that the previously reported change in ATP secretion [15] is only one of the effects of ABCC6 deficiency. In this scenario, the PXE syndrome might be considered a complex metabolic disorder not related to the mere absence of PPi in the plasma.

Abbreviations

ABC: ATP binding cassette; ACDC: Arterial calcification due to deficiency of CD73; CD73: Cluster of differentiation 73; DCC: Dystrophic cardiac calcification; GACl: Arterial calcification of infancy; GSH: Reduced glutathione; GSSG: Oxidized glutathione; OPN: Osteopontin; PXE: Pseudoxanthoma elasticum; ROS: Reactive oxygen species; SA- $\beta$-gal: Senescenceassociated $\beta$-galactosidase; TNAP: Tissue nonspecific alkaline phosphatase

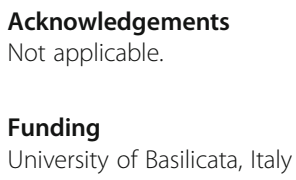

Availability of data and materials

Not applicable.

Authors' contributions

RM generated the stable HepG2 clones with ABCC6 silencing. AO performed the RT-PCR assays and analyses. MFA performed the western blot assays and analyses. LM performed the senescence assay. EC performed all the cellular cycle assessments. MC supervised the experiments. FB designed the experiments. All authors read and approved the final manuscript. 


\section{Consent for publication}

Not applicable.

\section{Ethics approval and consent to participate}

Not applicable.

\section{Publisher's note}

Springer Nature remains neutral with regard to jurisdictional claims in published maps and institutional affiliations.

\section{Author details}

${ }^{1}$ Department of Sciences, University of Basilicata, Via dell'Ateneo Lucano, 85100 Potenza, Italy. ${ }^{2}$ Institute of

Experimental Endocrinology and Oncology (IEOS), National Research Council (CNR), 80131 Naples, Italy.

Received: 15 September 2016 Accepted: 2 March 2017

Published online: 04 April 2017

\section{References}

1. Bergen AA, Plomp AS, Schuurman EJ, Terry S, Breuning M, Dauwerse $H$, et al. Mutations in ABCC6 cause pseudoxanthoma elasticum. Nat Genet. 2000;25:228-31.

2. Le Saux O, Urban Z, Tschuch C, Csiszar K, Bacchelli B, Quaglino D, et al. Mutations in a gene encoding an ABC transporter cause pseudoxanthoma elasticum. Nat Genet. 2000;25:223-7.

3. Ringpfeil F, Lebwohl MG, Christiano AM, Uitto J. Pseudoxanthoma elasticum: mutations in the MRP6 gene encoding a transmembrane ATP-binding cassette (ABC) transporter. Proc Natl Acad Sci U S A. 2000;97:6001-6,

4. Nitschke Y, Baujat G, Botschen U, Wittkampf T, Du Moulin M, Stella J, et al. Generalized arterial calcification of infancy and pseudoxanthoma elasticum can be caused by mutations in either ENPP1 or ABCC6. Am J Hum Genet. 2012;90:25-39.

5. Meng H, Vera I, Che N, Wang X, Wang SS, Ingram-Drake L, et al. Identification of Abcc6 as the major causal gene for dystrophic cardiac calcification in mice through integrative genomics. Proc Natl Acad Sci U S A. 2007:104: 4530-5.

6. Aherrahrou Z, Doehring LC, Ehlers EM, Liptau H, Depping R, Linsel-Nitschke P, et al. An alternative splice variant in Abcc6, the gene causing dystrophic calcification, leads to protein deficiency in $\mathrm{C} 3 \mathrm{H} / \mathrm{He}$ mice. J Biol Chem. 2008; 283:7608-15.

7. Brampton C, Aherrahrou Z, Chen LH, Martin L, Bergen AA, Gorgels TG, et al. The level of hepatic ABCC6 expression determines the severity of calcification after cardiac injury. Am J Pathol. 2014;184:159-70.

8. Markello TC, Pak LK, St Hilaire C, Dorward H, Ziegler SG, Chen MY, et al. Vascular pathology of medial arteria calcifications in NT5E deficiency: implications for the role of adenosine in pseudoxanthoma elasticum. Mol Genet Metab. 2011;103:44-50.

9. Scheffer GL, Hu X, Pijnenborg AC, Wijnholds J, Bergen AA, Scheper RJ. MRP6 (ABCC6) detection in normal human tissues and tumors. Laboratory investigation; a journal of technical methods and pathology. 2002;82:515-8.

10. Belinsky MG, Chen ZS, Shchaveleva I, Zeng H, Kruh GD. Characterization of the drug resistance and transport properties of multidrug resistance protein 6 (MRP6, ABCC6). Cancer Res. 2002;62:6172-7.

11. Uitto J, Pulkkinen L, Ringpfeil F. Molecular genetics of pseudoxanthoma elasticum: a metabolic disorder at the environment-genome interface? Trends Mol Med. 2001;7:13-7.

12. Le Saux O, Bunda S, VanWart CM, Douet V, Got L, Martin L, et al. Serum factors from pseudoxanthoma elasticum patients alter elastic fiber formation in vitro. The Journal of investigative dermatology. 2006;126:1497-505.

13. Garcia-Fernandez Ml, Gheduzzi D, Boraldi F, Paolinelli CD, Sanchez P, Valdivielso P, et al. Parameters of oxidative stress are present in the circulation of PXE patients. Biochim Biophys Acta. 2008;1782:474-81.

14. Boraldi F, Annovi G, Guerra D, Paolinelli Devincenzi C, Garcia-Fernandez Ml, Panico F, et al. Fibroblast protein profile analysis highlights the role of oxidative stress and vitamin $\mathrm{K}$ recycling in the pathogenesis of pseudoxanthoma elasticum. Proteomics Clin Appl. 2009:3:1084-98.

15. Jansen RS, Küçükosmanoglu A, De Haas M, Sapthu S, Otero JA, Hegman I, et al. ABCC6 prevents ectopic mineralization seen in pseudoxanthoma elasticum by inducing cellular nucleotide release. Proc Natl Acad Sci U S A. 2013;110:20206-11.

16. Jansen RS, Duijst S, Mahakena S, Sommer D, Szeri F, Váradi A, et al. ABCC6-mediated ATP secretion by the liver is the main source of the mineralization inhibitor inorganic pyrophosphate in the systemic circulation-brief report. Arterioscler Thromb Vasc Biol. 2014;34:1985-9.

17. Miglionico R, Gerbino A, Ostuni A, Armentano MF, Monné M, Carmosino M, et al. New insights into the roles of the N-terminal region of the ABCC6 transporter. J Bioenerg Biomembr. 2016;48:259-67.

18. Ostuni A, Miglionico R, Monné M, Castiglione Morelli MA, Bisaccia F. The nucleotide-binding domain 2 of the human transporter protein MRP6. J Bioenerg Biomembr. 2011;43:465-71.

19. Ostuni A, Miglionico R, Castiglione Morelli MA, Bisaccia F. Study of the nucleotide-binding domain 1 of the human transporter protein MRP6. Protein and peptide letters. 2010;17:1553-8.

20. Miglionico R, Armentano MF, Carmosino M, Salvia AM, Cuviello F, Bisaccia F, Ostuni A. Dysregulation of gene expression in ABCC6 knockdown HepG2 cells. Cell Mol Biol Lett. 2014;19:517-26.

21. Dimri GP, Lee X, Basile G, Acosta M, Scott G, Roskelley C, et al. A biomarker that identifies senescent human cells in culture and in aging skin in vivo. Proc Natl Acad Sci U S A. 1995;92:9363-7.

22. Pasquali-Ronchetti I, Garcia-Fernandez MI, Boraldi F, Quaglino D, Gheduzzi D, De Vincenzi PC, et al. Oxidative stress in fibroblasts from patients with pseudoxanthoma elasticum: possible role in the pathogenesis of clinical manifestations. J Pathol. 2006;208:54-61.

23. Jouan E, Le Vée M, Denizot C, Parmentier Y, Fardel O. Drug Transporter Expression and Activity in Human Hepatoma HuH-7 Cells. Pharmaceutics. 2016;9:3. doi:10.3390/pharmaceutics9010003. 
24. Zhang H, Limphong P, Pieper J, Liu Q, Rodesch CK, Christians E, et al. Glutathione-dependent reductive stress triggers mitochondrial oxidation and cytotoxicity. FASEB J. 2012;26:1442-51.

25. Nkabyo YS, Ziegler TR, Gu LH, Watson WH, Jones DP. Glutathione and thioredoxin redox during differentiation in human colon epithelial (Caco-2) cells. Am J Physiol Gastrointest Liver Physiol. 2002;283:G1352-9.

26. Markovic J, Mora NJ, Broseta AM, Gimeno A, De-la-Concepción N, Viña J, et al. The depletion of nuclear glutathione impairs cell proliferation in 3 t3 fibroblasts. PLoS ONE. 2009;4, e6413.

27. Debacq-Chainiaux F, Erusalimsky JD, Campisi J, Toussaint O. Protocols to detect senescence-associated betagalactosidase (SA-betagal) activity, a biomarker of senescent cells in culture and in vivo. Nat Protoc. 2009;4:1798-806.

28. Barascu A, Le Chalony C, Pennarun G, Genet D, Zaarour N, Bertrand P. Oxydative stress alters nuclear shape through lamins dysregulation: a route to senescence. Nucleus (Austin, Tex). 2012;3:411-7.

29. Akoglu G, Li Q, Gokoz O, Gazyagci AS, Uitto J. Clinical and histopathological characteristics of a family with R1141X mutation of pseudoxanthoma elasticum - presymptomatic testing and lack of carrier phenotypes. Int J Dermatol. 2014;53:692-8.

30. Li Q, Jiang Q, Uitto J. Pseudoxanthoma elasticum: oxidative stress and antioxidant diet in a mouse model (Abcc6 ${ }^{-/}$). J Invest Dermatol. 2008;128:1160-4.

31. Paul MK, Bisht B, Darmawan DO, Chiou R, Ha VL, Wallace WD, et al. Dynamic changes in intracellular ROS levels regulate airway basal stem cell homeostasis through Nrf2-dependent Notch signaling. Cell Stem Cell. 2014;15:199-214.

32. Deng X, Gao F, May WS. BCl2 retards G1/S cell cycle transition by regulating intracellular ROS. Blood. 2003;102:3179-85.

33. Arrigo AP. Gene expression and the thiol redox state. Free Radic Biol Med. 1999;27:936-44.

34. De Boussac H, Ratajewski M, Sachrajda I, Köblös G, Tordai A, Pulaski L, et al. The ERK1/2-hepatocyte nuclear factor 4alpha axis regulates human ABCC6 gene expression in hepatocytes. J Biol Chem. 2010;285:22800-8.

35. Carmosino M, Torretta S, Procino G, Gerbino A, Forleo C, Favale S, Svelto M. Role of nuclear Lamin A/C in cardiomyocyte functions. Biol Cell. 2014;106:346-58.

36. Coppé JP, Patil CK, Rodier F, Sun Y, Muñoz DP, Goldstein J, et al. Senescence-associated secretory phenotypes reveal cell-nonautonomous functions of oncogenic RAS and the p53 tumor suppressor. PLoS Biol. 2008;6:2853-68.

37. Coppé JP, Desprez PY, Krtolica A, Campisi J. The senescence-associated secretory phenotype: the dark side of tumor suppression. Annu Rev Pathol. 2010;5:99-118.

38. Irvine KM, Skoien R, Bokil NJ, Melino M, Thomas GP, Loo D, et al. Senescent human hepatocytes express a unique secretory phenotype and promote macrophage migration. World I Gastroenterol. 2014;20:17851-62.

39. Rasmussen MR, Nielsen KL, Laursen MR, Nielsen CB, Svendsen P, Dimke H, et al. Untargeted metabolomics analysis of ABCC6-deficient mice discloses an altered metabolic liver profile. J Proteome Res. 2016;15:4591-600.

\section{Submit your next manuscript to BioMed Central and we will help you at every step:}

- We accept pre-submission inquiries

- Our selector tool helps you to find the most relevant journal

- We provide round the clock customer support

- Convenient online submission

- Thorough peer review

- Inclusion in PubMed and all major indexing services

- Maximum visibility for your research

Submit your manuscript at www.biomedcentral.com/submit

O BioMed Central 